\title{
Millenial Consumer Syndrome in a Developing Nation: Exploring the Attitude of Nigerians to Locally Made Goods
}

\author{
Gloria Vincent-Osaghae, PhD \\ Department of Sociology \& Anthropology, \\ Faculty of Social Sciences, University of Benin, \\ Benin City, Nigeria \\ Ernest Osas Ugiagbe, PhD \\ Department of Social Work, \\ Faculty of Social Sciences, University of Benin, \\ Benin City, Nigeria \\ Corresponding Author
}

Doi: $10.2478 / \mathrm{mjss}-2018-0057$

\begin{abstract}
Today the Nigerian consumer seems to be undergoing a shift in terms of personality, buying motives, interest, attitudes, beliefs, and values when he or she opts for imported rather than locally made goods. This study empirically explores the attitude of Nigerians towards locally made goods in Benin Metropolis, Edo State, Nigeria. The study adopted the survey research design and both quantitative and qualitative sources of data collection were employed. A total of 420 questionnaires were administered to the research participants using the stratified random sampling method but 400 questionnaires were eventually used for analysis because 20 questionnaires were rejected for mutilations. The data collected were analyzed with aid of inferential statistics and variables were cross-tabulated. The findings revealed that the effects of band wagon, peer influence and the belief that foreign goods are superior in quality to locally manufactured goods because of their high level of durability make Nigerians to crave for foreign goods. This has far reaching socio-economic impact on the quest to bring about sustainable development in Nigeria. Recommendations on how to remedy the situation were made in order to positively influence Nigerians 'attitude to locally made goods.
\end{abstract}

Keywords: Attitude; consumer behaviour; made in Nigeria goods; foreign made goods; Durability

\section{Background of the Study}

Attitude refers to the general and relatively enduring evaluations people have of other people, objects, or ideas. These overall evaluations can be positive, negative, or neutral, and can vary in their extremity. For example, one individual might view exercise in a mildly positive way, whereas another might be wildly positive, and another might be somewhat negative. Individuals can hold different attitudes about very broad or abstract constructs (e.g. freedom) as well as very concrete and specific things (e.g. a particular brand of chewing gum), that is, people tend to act favourably toward things they like (e.g. marriage, music) and unfavourably toward things they do not like (Church, 2006; Petty, 2003).

Interestingly, people are not necessarily aware of the basis of their attitudes. For example, people can believe that their attitudes are based primarily on cognition when they are in fact based on affect, and both meta-and-structural bases of attitudes influence how people respond to making 
choices between locally made and imported goods (Petty 2003). Consumers, in making choices among goods and services, have to evaluate what it is that they want. In other words, they have to look at their total complex of wants decide how far they are going to go in satisfying their wants for shelter and protection, how far they are going to go in satisfying their wants for food, their want for contact with social groups, their want to be fashionable and so on, within the limits of their resources. The decisions of consumers have at least three aspects: First, they have to make decisions as to which wants are to be satisfied; secondly, they must decide the degree to which each want is to be satisfied and third which combination of goods and services is to be acquired from the whole array available? (Bivens 2013)

This study explores the attitudes of Nigerians towards locally made goods. The study specifically investigates the perceptual/attitudinal dispositions of Nigerians towards made in Nigeria goods in the context of their class, sex, age and other social differentials and whether the attitudes are influenced by the perceived cognition of the qualities and other traits of locally manufactured goods and imported goods.

\section{Statement of the Problem}

In times of economic crisis, people's attitudes towards investing and spending money are changing. While the financially worse off consumers tend to buy cheaper products, such as private labels, non-branded or even "fake goods", rich consumers on the other hand invest more in products on the opposite end of the price scale by spending more on luxury goods (Penz, Schlegemilch and Stottinger, 2009 in Kasl Kollmannova, 2012).

The lifestyle of Nigerians have changed and are still changing in tandem with globalizing World. Today, what seem to be in vogue is ability or capability to buy goods especially imported goods of all kinds and this is a form of measurement of status symbols of the rich and middle class. Hence, the Nigerian markets are flooded with foreign made goods of all kinds - beverages, clothes, fabrics, processed foods, electronic gadgets, shoes, Jewries and a host of others. Most of these goods are 'tokumbo" 'fairly' used supposedly repacked from the dumps in charity stores all over metropolitan centres in Europe, Asian nations, the U S A, North and South Africa. The desire and craze for these foreign goods are alarming and Nigeria has unarguably become a dumping ground for all kinds of goods. But the question is why the preference for foreign goods and disdain for locally manufactured goods?

\section{Objectives of the Study}

The main aim of this study is to explore in general terms the consumer behaviour and attitude towards locally made goods in Nigeria using Benin metropolis as a case study. Other specific objectives are as follows:

(i) To investigate the impact of income on the consumer attitude of Nigerians to local and foreign goods.

(ii) To identify compelling factors that influence purchase intention of locally made goods.

(iii) To examine how socio-demographic variables such as age, sex, income, occupation, etc. affect consumers' attitude towards made in Nigeria goods.

\section{Hypotheses}

The following hypotheses were used to evaluate or test the data collected for the study:

(i) There is no significant difference between income and attitude towards made in Nigeria goods.

(ii) There is no significant difference between occupation and attitude towards made in Nigeria goods.

(iii) There is no significant difference between quality of goods and attitude towards locally made goods. 


\section{Significance of the Study}

Nigeria is a dumping ground for all manner of goods from all over the world and this is inimical to Nigeria's quest for sustainable development in all its ramifications. There is therefore the need for concerted efforts by all stakeholders to redress and reverse the unwholesome preference for foreign goods. This is one sure way of revamping the comatose economy and also create jobs for Nigerians.

The study is very significant because it is an invaluable asset in both theoretical and empirical terms. Theoretically, the findings of this study help to add to existing literature on attitude and consumer behaviour in the context of the perception of goods by consumers in a developing economy. The study is also be of immense benefit to the empirical understanding of consumer behaviour especially the preference for foreign goods and disdain for some local goods by Nigerians. The empirical evidence/findings of this study add to already literature on attitude. It is also be a stepping stone for further research into this important social phenomenon and expand the process and frontiers of knowledge on attitude, behaviour and perception of goods by the teeming consumers in Nigeria.

A study of this nature that examines the issue of consumer behaviour and attitude of Nigerians towards locally manufactured goods has a significant contribution to make to sustainable development. This is because it provide a better understanding of the phenomenon and dynamics of consumer behaviour among Nigerians in such a way that the intensity of the problem and other hidden dimensions to the issue of consumer behaviour can be illuminated particularly in contemporary Nigeria where emphasis is being increasingly placed on sustainable development through the resuscitation of the potentials of local entrepreneurs and owners of small scale enterprises.

\section{Brief Literature Review}

There is a link between a positive attitude towards a product and the purchasing power behaviour (Petty, 2001). Attempts of finding solutions came up with the theory of Reasoned Action (Fishbien \& Ajzen, 1980), which attempts to link a product attitude to the intention to purchase and the frequency of past purchasing, and then predicting the purchase behaviour.

According to Lehman (1979) in Igbinovia and Ugiagbe (2006) the determinants of value are the attributes of a product that create value to the consumers. Those attributes go beyond the tangible characteristics of the product, involving also the augmented product. The process of identifying the determinants of values then involves finding which attributes are the most important to the consumers. Determinants of value can also be seen as products attributes that might differentiate one brand from another, when a consumer is choosing between one or more products (Krosnick, 1988). A consumer's overall evaluation of a product accounts for the most of his/her attitude and also the attributes of the products that usually affect the purchase behaviour of people are: Quality of the products. This is perhaps the most compelling factor that influence people attitude towards goods in all nations of the world. Goods of high quality always compel consumers to go for them, and consequently the demand for the good.

Secondly, variety is the spice of life hence the more assorted the goods the higher the demand and positive attitude for the good by the consumers. A good knowledge of the goods quality will always endear consumers to go for them. The goods by affinity will always attract people hence some high quality manufactured goods are always in high demands all over the world. Another important factor is the price of the product and this is also predicated on the status of consumers. Cheap goods will attract the attention of the poor and lower class members of the society while the rich will always go for expensive goods because they have taste and class consciousness. Lastly, availability of goods and past experience about some goods greatly influence the attitude of consumers towards the goods. 


\section{Theoretical Orientation}

The study was informed by two theories; namely, social penetration and attribution theories

\section{Social Penetration Theory}

Social penetration theory was propounded by Althman and Taylor (1973) who affirms that personal disclosure and sharing of information in purchasing of goods is important and this largely depends on consumers/buyers attitude and belief about the product(s).

Taylor and Todd (1995) posited that behaviours attitude toward any object is linked to trust and the trust is a result of relatively long time of interaction and dealings in that particular good(s)/object(s). Successful interaction of an individual with specific good(s) in terms of their qualities like durability, performance, etc. enhances individual attitude and beliefs about the good(s). In this context, the consistent association with and use of Nigerian made goods and imported goods help to form an enduring attitude, belief and preference towards imported goods vis.-a-vis. locally made Nigerian goods.

This theory explains the reasons why Nigerians crave for imported goods because of the social penetration (trust) they have for such goods over the years hence the trust for locally made good is low because experience had taught the users that the goods are inferior in quality to imported goods in all ramifications.

\section{Attribution Theory of Consumer Behaviour}

Attribution theory is the theory of why we attribute outcome $X$ to causal factor $Y-$ in short, who or what do we hold responsible for the outcome? Attribution theorists generally recognize two variables that influence our attribution: dispositional/situational, and stable/unstable (www.psychologynoteshq.com/attributiontheory). For example, Bobby et al (1977) reported that attribution theory addresses the inferences people make about themselves and others after witnessing behaviour and the situational constraints surrounding those behaviours. Attribution theory is used to develop a new approach to interpersonal influence. As a first step in investigating this approach, an experiment explores how people infer personal dispositions from observing a consumer's behavior. The results illustrate the value of the attribution approach but suggest the need for extending existing attribution theory.

In Nigeria, persuasions are usually in form of bandwagon effect. The bandwagon effect in Nigeria is the craze for imported goods. The popular belief is that fairly used goods no matter how old are of better quality and durability than the locally manufactured goods in Nigeria hence Nigerians are massively patronizing the selling points and stores of used and imported goods. The theory of attribution best explains the Nigerian preference for imported goods because they attribute their attitude and behaviour to the traits, qualities and other information about the imported goods based on their lived experiences with the goods [imported and locally made] hence they are able to deduce from handling the goods that imported goods are of better quality than the locally made goods.

\section{Research Methods}

The survey research design was adopted in sourcing for data for the study. The study area of this research are the markets in Benin metropolis. Benin City is the political and economic capital of Edo State and the traditional headquarters of the Benin people of South-South Nigeria. Benin City is politically subdivided into three Local Government Areas viz.: Oredo, Egor and Ikpoba-Okha. Benin City can aptly be regarded as the business hub of Edo State and the city centre is the Central Business District (CBD) of the Metropolis. The choice of these markets in the study area is informed by the fact that the markets are unarguably the busiest and most patronised by all and sundry and the markets where most imported goods are displayed for sale and sought after by prospective Nigerian buyers. 
The population of this study consists of the entire population of Benin metropolis resident in the study area. This means the population of three local government areas which make up Benin City. According to the 2014 projection, the population of the residents of the three Local Government Areas making up Benin-City are Egor - 340,287; Ikpoba-Okha- 372,080 and Oredo 374,515 , making a total of $\mathbf{1 , 1 1 6 , 8 7 9}$

The entire people of this study area who do their shopping in the markets listed below formed the population of the study.

The sample size for this study consisted of four hundred participants who patronise the selected markets for shopping. The 400 (four hundred) participants are a fair representative sample of the entire population of the study.

The sample frames are draw from the population as below:

\begin{tabular}{ll} 
New Benin market & 80 \\
Ekiosa market & 80 \\
Edaiken market- & 80 \\
Oregbeni markets & 80 \\
Oba market & 80 \\
Total & $\underline{400}$ \\
\hline
\end{tabular}

The five (5) markets selected for this study were purposively selected because they are the most popular and patronised markets in Benin Metropolis and the final destinations of most shoppers in and out of seasons, and also where most goods of local and foreign origins are displayed for sale.

The final identification and administration of questionnaires to the research participants were attained through the disaggregation of the selected markets into its constituent units. The units within the markets are according to the wares available in each unit. To this end, the units for food stuffs, clothes and fabrics, shoes and fairly used materials, groundnut and palm oil, electronics and accessories and perishable raw foods amongst others are segregated. The participants of this research were contacted in the clothes and fabrics, used clothes and shoes and groundnut/palm oil dealers' sections of the selected markets.

A total of 400 participants were administered the questionnaire. The four units IN the selected markets where the participants were contacted were: Shoes and foot wears unit 20; Clothes and fabrics unit 20; Used clothes unit 20 and Palm/groundnut oil unit 20. This total 80 , which is 20 participants were contacted from each unit from the selected markets. The structured questionnaires were administered to customers who patronised the markets selected for this study. The questionnaire was divided into two sections: sections A and B. Section A dealt with the information relating to the bio-data profile of the research participants such as age, marital status, highest educational level, religion, ethnic group and occupation amongst others. Section B focused on participants' perception and attitude towards locally made goods and related issues. The indepth interview was organized for shop/stall owners in the markets.

The data collected in this study were analysed with the SPSS version 8 . The raw data were coded after the major characteristics, themes and patterns of responses have been handled effectively. The results were presented in frequency distribution, simple percentage and tabulation. The data were analysed and cross- tabulated with chi-square $\left(\chi^{2}\right)$ and other standardised statistics were used to test the hypotheses earlier generated for this study.

\section{Findings}

\subsection{Socio-Demographic Characteristics of the Participants}

The frequency distribution and sample characteristics of all the socio-demographic variables are presented below. 
Table 1: Socio-Demographic Characteristics of the Participants

\begin{tabular}{|c|c|c|c|}
\hline Socio-Demographic Characteristics & Response & Frequency & Percentage \\
\hline \multirow{3}{*}{ Sex Of Participants } & Male & 213 & 53.2 \\
\hline & Female & 187 & 46.8 \\
\hline & Total & 400 & 100.0 \\
\hline \multirow{7}{*}{ Age Of Participants } & $18-25$ & 152 & 38.0 \\
\hline & $26-30$ & 104 & 26.0 \\
\hline & $31-35$ & 32 & 8.0 \\
\hline & $36-40$ & 19 & 4.8 \\
\hline & $41-45$ & 9 & 2.2 \\
\hline & $46-50$ and above & 84 & 21.0 \\
\hline & Total & 400 & 100.0 \\
\hline \multirow{7}{*}{ Participants State Of Origin } & Edo 152 & 38.0 & 152 \\
\hline & $\begin{array}{ll}\text { Delta } & 104 \\
\end{array}$ & 26.0 & 104 \\
\hline & $\begin{array}{ll}\text { Imo } & 32 \\
\end{array}$ & 8.0 & 32 \\
\hline & Ondo & 4.8 & 19 \\
\hline & Enugu & 2.2 & 9 \\
\hline & Other states 84 & 21.0 & 84 \\
\hline & 400 & 100.0 & 400 \\
\hline \multirow{4}{*}{ Distribution of Participants By Religion } & Christianity & 389 & 97.2 \\
\hline & Islam & 8 & 2.0 \\
\hline & ATR & 3 & 8 \\
\hline & Total & 400 & 100.0 \\
\hline \multirow{6}{*}{ Distribution of Participants By Income Level } & $\mathrm{N} 20,000-\mathrm{N} 40,000$ & 171 & 42.8 \\
\hline & $\mathrm{N} 41,000-80,000$ & 90 & 22.5 \\
\hline & N81,000-120,000 & 53 & 13.2 \\
\hline & Above N121, 000 & 33 & 8.2 \\
\hline & Others & 53 & 13.2 \\
\hline & Total & 400 & 100.0 \\
\hline \multirow{4}{*}{ Distribution of Participants By Marital Status } & Married & 168 & 42.0 \\
\hline & Single & 222 & 55.5 \\
\hline & Divorced & 10 & 2.5 \\
\hline & Total & 400 & 100.0 \\
\hline \multirow{7}{*}{ Distribution of Participants By Education } & Primary & 8 & 2.0 \\
\hline & Secondary & 48 & 12.0 \\
\hline & Technical school & 5 & 1.2 \\
\hline & NCE, OND \&HND & 68 & 17.0 \\
\hline & B.Sc., M.Sc. \& above & 241 & 60.2 \\
\hline & Other & 30 & 7.5 \\
\hline & Total & 400 & 100.0 \\
\hline \multirow{6}{*}{ Distribution of Participants By Occupation } & Artisan & 16 & 4.0 \\
\hline & Civil servant & 146 & 36.5 \\
\hline & Unemployed & 96 & 24.0 \\
\hline & Self employed & 97 & 24.2 \\
\hline & Students & 45 & 11.2 \\
\hline & Total & 400 & 100.0 \\
\hline
\end{tabular}

Source: Field Survey by the authors, 2016

The result of Table 1 above shows that there were more males $213(53.2 \%)$ than females $187(46.8 \%)$. The age of participants shows that majority of the participants representing $152(38.0 \%)$ 
are between 18-25 years of age, while those participants $104(26.0 \%)$ were between 26-30 years of age $32(8.0 \%)$ were between the ages of $31-35$ years. Also $19(4.8 \%)$ were between the ages of $36-$ 40 years however, $9(2.2 \%)$ were between the ages of $41-40$ years and $84(21.0 \%)$ were between 46 and above. The study shows the minimum age of the participants as 18 years while the maximum is 50 years. It also shows that the mean age of the participants is 40 .

The religious affiliation of the participants' shows that majority of the respondents representing $389(97.2 \%)$ were Christians, while the Moslems constitute $8(2.0 \%)$. The remaining $3(.8 \%)$ represents the believers of African traditional religion. The result of the above table may not be strange and surprising since the study was carried out in Benin City that is predominantly Christians. The majority of the participants representing $171(42.8 \%)$ earned N20, 000-N40, 000 , while those participants $90(22.5 \%)$ earned between N41, 000-N80, 000 then $53(13.2 \%)$ earned between N81, 000-120,000. Also 33(8.2\%) earned between N121, 000 and above and $53(13.2 \%)$ did not belong to these categories. The marital status of the participants from Table 1 indicates that the participants who were married rated $168(42.0 \%)$ while $222(55.5 \%)$ were single and $10(2.5 \%)$ were divorced.

Moreover, the result of Table 1 shows that majority of the participants, 241(60.2\%) have B.Sc. /M.Sc. and above while the least number of participants $5(1.2 \%)$ had technical school education. But $68(17.0 \%)$ had NCE/OND and HND, 48(12.0\%) had secondary school education $8(2.0 \%)$ had primary school certificate, the implication is that majority of the respondents are well educated. Furthermore, the result of Table 1 shows that majority of the participants with $146(36.5 \%)$ were civil servants while $97(24.2 \%)$ are self-employed. The large number of the participants being civil servants could be a proof that Benin City is a civil service.

Table 2: Reasons for buying Nigerian or foreign good

\begin{tabular}{|c|c|c|c|}
\hline & Responses & Frequency & $\begin{array}{c}\text { Percentage } \\
(\%)\end{array}$ \\
\hline \multirow{6}{*}{$\begin{array}{l}\text { Distribution of Participants on what factors } \\
\text { influence their choice of goods in the } \\
\text { market whether foreign or Nigerian made } \\
\text { (Factor that influence their choices) }\end{array}$} & Durability & 249 & 62.2 \\
\hline & Availability & 34 & 8.5 \\
\hline & Profitability & 27 & 6.8 \\
\hline & Price & 84 & 21.0 \\
\hline & All of the above & 6 & 1.5 \\
\hline & Total & 400 & 100.0 \\
\hline \multirow{4}{*}{$\begin{array}{l}\text { Distribution of Participants opinion on } \\
\text { opportunity to buy goods of any kind; } \\
\text { Which goods will they prefer (Goods of any } \\
\text { kind) }\end{array}$} & Nigerian made & 89 & 22.2 \\
\hline & Foreign made & 255 & 63.8 \\
\hline & Cannot tell & 56 & 14.0 \\
\hline & Total & 400 & 100 \\
\hline \multirow{10}{*}{$\begin{array}{l}\text { Distribution of Participants on their reasons } \\
\text { for home made goods }\end{array}$} & Because home made goods are better & 9 & 2.2 \\
\hline & None & 291 & 72.8 \\
\hline & $\begin{array}{l}\text { It helps to promote made in Nigeria goods and job } \\
\text { opportunity i.e. develop the economy of the country }\end{array}$ & 55 & 13.8 \\
\hline & To be a good Nigerian & 3 & 8 \\
\hline & $\begin{array}{l}\text { Because I am an African man i.e. I am proud of the } \\
\text { product }\end{array}$ & 8 & 2.0 \\
\hline & $\begin{array}{l}\text { Because Nigerian made is good/stands for Nigerian } \\
\text { weather }\end{array}$ & 9 & 2.2 \\
\hline & $\begin{array}{l}\text { Because one is sure of what is used for the } \\
\text { production }\end{array}$ & 5 & 1.2 \\
\hline & Because the price is low & 9 & 2.2 \\
\hline & Because the home made is always available to buy & 11 & 2.8 \\
\hline & Total & 400 & 100.0 \\
\hline \multirow{6}{*}{$\begin{array}{l}\text { Distribution of Participants on their reasons } \\
\text { for preference for foreign goods } \\
\text { (Reasons for buying foreign made goods) }\end{array}$} & Because most times they tend to be solid & 42 & 10.5 \\
\hline & None & 121 & 30.2 \\
\hline & They last longer because of the quality and durability & 209 & 52.2 \\
\hline & Because of originality and availability & 13 & 3.2 \\
\hline & If the price is not too high & 15 & 3.8 \\
\hline & Total & 400 & 100.0 \\
\hline \multirow{2}{*}{\begin{tabular}{|l} 
Distribution of Participants on socio- \\
economic and cultural factors that informs
\end{tabular}} & Income & 286 & 71.5 \\
\hline & Culture & 40 & 10.0 \\
\hline
\end{tabular}




\begin{tabular}{|c|c|c|c|}
\hline & Responses & Frequency & $\begin{array}{c}\begin{array}{c}\text { Percentage } \\
(\%)\end{array} \\
\end{array}$ \\
\hline \multirow{4}{*}{$\begin{array}{l}\text { their choice of goods when making a } \\
\text { purchase }\end{array}$} & Parents & 5 & 1.2 \\
\hline & Government action & 28 & 7.0 \\
\hline & History & 41 & 10.2 \\
\hline & Total & 400 & 100.0 \\
\hline \multirow{4}{*}{$\begin{array}{l}\text { Do you buy goods because others are } \\
\text { buying it }\end{array}$} & Yes & 21 & 5.2 \\
\hline & No & 345 & 86.2 \\
\hline & Do not know & 34 & 8.5 \\
\hline & Total & 400 & 100.0 \\
\hline \multirow{7}{*}{$\begin{array}{l}\text { Distribution of Participants on imported } \\
\text { goods they prefer to always (Prefer } \\
\text { imported goods) }\end{array}$} & Shoes & 184 & 46.0 \\
\hline & Fairly used clothes & 40 & 10.0 \\
\hline & Wines and spirits & 12 & 3.0 \\
\hline & All imported goods & 152 & 38.0 \\
\hline & Depend on my needs at that time & 3 & .8 \\
\hline & None of the above & 9 & 2.2 \\
\hline & Total & 400 & 100.0 \\
\hline \multicolumn{4}{|c|}{$\begin{array}{l}\text { Distribution of Participants on whether they prefer Nigerian goods if improved upon in terms of quality and } \\
\text { durability to foreign made goods }\end{array}$} \\
\hline \multirow{3}{*}{$\begin{array}{l}\text { Will you prefer Nigerian goods if improved } \\
\text { upon to foreign goods? }\end{array}$} & Yes & 316 & 79.0 \\
\hline & No & 84 & 21.0 \\
\hline & Total & 400 & 100.0 \\
\hline \multicolumn{4}{|c|}{ Distribution on participants on their reason for goods } \\
\hline \multirow[t]{8}{*}{ Reason for goods made } & Poor quality & 151 & 37.8 \\
\hline & Imitations & 36 & 9.0 \\
\hline & Not easily available & 8 & 2.0 \\
\hline & \begin{tabular}{|l|} 
No consistency in quality \\
\end{tabular} & 133 & 33.2 \\
\hline & Too much fake and adulterated & 66 & 16.5 \\
\hline & Very high quality & 3 & .8 \\
\hline & Others & 3 & .8 \\
\hline & Total & 400 & 100.0 \\
\hline
\end{tabular}

The result of Table 2 above shows that majority of the participants; $249(62.2 \%)$ valued durability while $84(21.0 \%)$ go for the price of the goods, but $34(8.5 \%)$ were influenced by availability of the goods. Also $27(6.8 \%)$ prefer profitability of the goods. This indicates that durability of products is the motivating factor that influences people's choice of goods. The result of Table 2 equally shows that majority of the participants i.e. $255(63.8 \%$ ) declared that if given the opportunity, they will buy foreign made goods while $89(22.2 \%)$ said they will buy Nigerian made goods. This indicates that the participants prefer to buy foreign made good than Nigerian made goods.

The result of Table 2 also shows that majority of the participants i.e. 291(72.8\%) were undecided while 55(13.8\%) said it helps to promote made in Nigerian goods and job creation i.e. help develop the economy of the country but $11(2.8 \%)$ said that home made goods are always available. Also 9(2.2\%) opined that home made goods are better because Nigerian made goods are weather friendly and also price friendly. Other participants based their preference on patriotism i.e. they are proud of made in Nigeria products. This indicates that majority of the participants were not persuaded to buy made in Nigeria products.

The result of Table 2 further shows that majority of the participants i.e. $209(52.2 \%)$ were of the opinion that foreign goods last longer because of the quality and durability while $121(30.2 \%)$ were undecided. This indicates that majority of the participants have a very strong reason for buying foreign made goods. Also, majority of the participants, that is $286(71.5 \%)$ opined that income is what guides their choice of goods when making a purchase while $41(10.2 \%)$ said it is past experience $28(7.0 \%)$ and government actions like fiscal control. This shows that income of an individual is what influences his/her choice of goods to purchase. Majority of the participants i.e. $345(86.2 \%)$ do not purchase goods because others are buying the same goods while $34(8.5 \%)$ are undecided. This reveals that majority of the participants take personal decision when making their choices to buy any kind of goods.

The result of Table 2 shows that majority of the participants i.e. 184(46.0\%) prefers to buy imported shoes while $152(38.0 \%)$ prefer to buy all imported goods but $40(10.0 \%)$ prefers to buy fairly used clothes and $12(3.0 \%)$ prefer to buy wines and spirits This shows that majority of the 
participants prefer to buy imported shoes and all imported goods.

The result of Table 2 shows that majority of the participants, that is $316(79.0 \%)$ prefer Nigerian goods if the quality is improved upon and $84(21.0 \%)$ will not still buy Nigerian made goods irrespective of the quality. This shows that majority of the participants attach stereotypes to Nigerian made goods because majority of the participants i.e. $151(37.8 \%)$ believe that the poor quality of Nigerian made goods discourage them while 133(33.2\%) opined that Nigerian goods have no consistency in quality and worse still, 66(16.3\%) think Nigeria goods are always fake and adulterated. This shows that majority of the participants have a negative stereotypic opinion about made in Nigeria goods as being poorly produced in terms of the quality.

\subsection{Cross tabulation of research variables}

The aim of this sub-section is to assess the overall consumer behaviour toward locally made goods i.e. made in Nigeria goods in Benin Metropolis. The attitude of participants towards locally made goods was tested to determine the participants' choices to buy made in Nigeria goods, those with positive choices and those with negative choices respectively. Chi-square $\left(x^{2}\right)$ test was used to determine whether there was a significant relationship between the variables.

Attitude towards Nigerian made goods was measured using four variables; sex, religion, marital status and education. These variables were selected from questionnaire items $1,5,7,8$, and 18.

Table 2: Cross tabulation of research variables

\begin{tabular}{|c|c|c|c|c|}
\hline \multirow[t]{2}{*}{ Sex } & \multicolumn{2}{|c|}{$\begin{array}{l}\text { If made in Nigeria goods are improved upon in terms of quality } \\
\text { and durability will prefer them to foreign goods }\end{array}$} & \multirow[t]{2}{*}{ Total } & \multirow{5}{*}{$\begin{array}{c}\mathrm{X}^{2}=(\mathrm{N}=400, \mathrm{df}=1)= \\
4.613, \mathrm{P} \leq .032\end{array}$} \\
\hline & Positive Attitude (Yes) & Negative Attitude (No) & & \\
\hline Male & $177(56.0 \%)$ & $36(42.9 \%)$ & $213(53.2 \%)$ & \\
\hline Female & $139(44.0 \%)$ & $48(57.1 \%)$ & $187(46.8 \%)$ & \\
\hline Total & $316(100 \%)$ & $84(100 \%)$ & $400(100 \%)$ & \\
\hline \multirow{2}{*}{ Religion } & \multicolumn{2}{|c|}{$\begin{array}{l}\text { If made in Nigeria goods are improved upon in terms of quality } \\
\text { and durability will prefer them to foreign goods }\end{array}$} & \multirow[t]{2}{*}{ Total } & \multirow{6}{*}{$\begin{array}{c}\mathrm{X}^{2}=(\mathrm{N}=400, \mathrm{df}=)= \\
2.118, \mathrm{P} \leq .347\end{array}$} \\
\hline & Positive Attitude (Yes) & Negative Attitude (No) & & \\
\hline Christianity & $308(97.5 \%)$ & $81(96.4 \%)$ & $389(97.2 \%)$ & \\
\hline Islam & $5(1.6 \%)$ & $3(3.6 \%)$ & $8(2.0 \%)$ & \\
\hline ATR & $3(.9 \%)$ & $0(.0 \%)$ & $3(.8 \%)$ & \\
\hline Total & $316(100 \%)$ & $84(100 \%)$ & $400(100 \%)$ & \\
\hline \multirow[t]{2}{*}{ Marital Status } & \multicolumn{2}{|c|}{$\begin{array}{l}\text { If made in Nigeria goods are improved upon in terms of quality } \\
\text { and durability will prefer them to foreign goods }\end{array}$} & & \multirow{5}{*}{$\begin{array}{c}\mathrm{X}^{2}=(\mathrm{N}=400, \mathrm{df}=1)= \\
.160, \mathrm{P} \leq .689\end{array}$} \\
\hline & Positive Attitude (Yes) & Negative Attitude (No) & & \\
\hline Married & $139(44.0 \%)$ & $39(46.4 \%)$ & $178(44.5 \%)$ & \\
\hline Single & $177(56.0 \%)$ & $45(53.6 \%)$ & $222(55.5 \%)$ & \\
\hline Total & $316(100 \%)$ & $84(100 \%)$ & $400(100 \%)$ & \\
\hline \multirow{2}{*}{$\begin{array}{l}\text { Level of } \\
\text { education }\end{array}$} & \multicolumn{2}{|c|}{$\begin{array}{l}\text { If made in Nigeria goods are improved upon in terms of quality } \\
\text { and durability will prefer them to foreign goods }\end{array}$} & \multirow[t]{2}{*}{ Total } & \multirow{5}{*}{$\begin{array}{c}X^{2}=(N=400, d f=1)= \\
1.693, P \leq .193\end{array}$} \\
\hline & Positive Attitude (Yes) & Negative Attitude (No) & & \\
\hline Low education & $52(16.5 \%)$ & $9(10.7 \%)$ & $61(15.2 \%)$ & \\
\hline High education & $264(83.5 \%)$ & $75(89.3 \%)$ & $339(84.8 \%)$ & \\
\hline Total & $316(100 \%)$ & $84(100 \%)$ & $400(100 \%)$ & \\
\hline \multirow{2}{*}{$\begin{array}{l}\text { Level of } \\
\text { education }\end{array}$} & \multicolumn{3}{|c|}{ If opportunity to buy goods of any kind which will you prefer } & \multirow{2}{*}{ Total } \\
\hline & Nigerian Made & Foreign Made & Can't say & \\
\hline Low education & $14(15.7 \%)$ & $38(14.9 \%)$ & $9(16.1 \%)$ & $61(15.2 \%)$ \\
\hline High education & $75(84.3 \%)$ & $217(85.1 \% 0$ & $47(83.9 \%)$ & $339(84.8 \%)$ \\
\hline Total & $89(100 \%)$ & $255(100 \%)$ & $56(100 \%)$ & $400(100 \%)$ \\
\hline
\end{tabular}

$\mathrm{X}^{2}=(\mathrm{N}=400, \mathrm{df}=2)=.069, \mathrm{P} \leq .96$ 


\section{Testing of Hypotheses}

\subsection{Hypothesis One}

\begin{tabular}{|c|c|c|c|c|c|c|}
\hline \multirow{2}{*}{ Age of participants } & \multicolumn{4}{|c|}{ What do you think about made in Nigeria goods } & \multirow[t]{2}{*}{ Total } & \multirow{5}{*}{$\begin{array}{c}X^{2}=(N=400, d f=3)= \\
13.771, P \leq .003\end{array}$} \\
\hline & Poor quality & Imitations & Not easily available & Very high quality & & \\
\hline Younger participants & $192(67.6 \%)$ & $85(83.3 \%)$ & $8(100 \%)$ & $3(50.0 \%)$ & $288(72.0 \%)$ & \\
\hline Older participants & $92(32.4 \%)$ & $17(16.7 \%)$ & $0(.0 \%)$ & $3(50.0 \%)$ & $112(28.0 \%)$ & \\
\hline Total & $284(100 \%)$ & $102(100 \%)$ & $8(100 \%)$ & $6(100 \%)$ & $400(100 \%)$ & \\
\hline
\end{tabular}

\subsection{Hypothesis Two}

\begin{tabular}{|c|c|c|c|c|c|c|}
\hline \multirow{2}{*}{$\begin{array}{l}\text { Income level of } \\
\text { participants }\end{array}$} & & & & & & \multirow{5}{*}{$\begin{array}{c}X^{2}=(N=400, d f=3)= \\
5.126, P \leq .163\end{array}$} \\
\hline & $\begin{array}{c}\text { Poor } \\
\text { quality }\end{array}$ & Imitations & $\begin{array}{c}\text { Not easily } \\
\text { available }\end{array}$ & $\begin{array}{l}\text { Very high } \\
\text { quality }\end{array}$ & Total & \\
\hline Low income & $182(64.1 \%)$ & $66(64.7 \%)$ & $7(87.5 \%)$ & $6(100 \%)$ & $261(65.2 \%)$ & \\
\hline High income & $102(35.9 \%)$ & $36(35.3 \%)$ & $1(12.5 \%)$ & $0(.0 \%)$ & $139(28.0 \%)$ & \\
\hline Total & $284(100 \%)$ & $102(100 \%)$ & $8(100 \%)$ & $6(100 \%)$ & $400(100 \%)$ & \\
\hline
\end{tabular}

\subsection{Hypothesis Three}

\begin{tabular}{|c|c|c|c|c|c|c|}
\hline \multirow{2}{*}{ Occupation leve } & \multicolumn{4}{|c|}{ What do you think about made in Nigeria goods } & \multirow{2}{*}{ Total } & \multirow{5}{*}{$\begin{array}{c}\mathrm{X}^{2}=(\mathrm{N}=400, \mathrm{df}=3)= \\
1.695, \mathrm{P} \leq .638\end{array}$} \\
\hline & Poor quality & Imitations & Not easily available & Very high quality & & \\
\hline Employed & $189(66.5 \%)$ & $62(60.8 \%)$ & $5(62.5 \%)$ & $3(50.0 \%)$ & $259(64.8 \%)$ & \\
\hline Unemployed & $95(33.5 \%)$ & $40(39.2 \%)$ & $3(37.5 \%)$ & $3(50.0 \%)$ & $141(35.2 \%)$ & \\
\hline Total & $284(100 \%)$ & $102(100 \%)$ & $8(100 \%)$ & $6(100 \%)$ & $400(100 \%)$ & \\
\hline
\end{tabular}

\subsection{Hypothesis Four}

\begin{tabular}{|c|c|c|c|c|c|c|}
\hline \multirow{2}{*}{ Quality of goods } & \multicolumn{4}{|c|}{ What do you think about made in Nigeria goods } & \multirow{2}{*}{ Total } & \multirow{5}{*}{$\begin{array}{c}\mathrm{X}^{2}=(\mathrm{N}=400, \mathrm{df}=3)= \\
35.314, \mathrm{P} \leq .000\end{array}$} \\
\hline & Poor quality & Imitations & Not easily available & Very high quality & & \\
\hline Yes & $214(75.4 \%)$ & 97(95.1\%) & $2(25.0 \%)$ & $3(50.0 \%)$ & $316(79.0 \%)$ & \\
\hline No & $70(24.6 \%)$ & $6(4.9 \%)$ & $6(75.0 \%)$ & $3(50.0 \%)$ & $84(21.0 \%)$ & \\
\hline Total & $284(100 \%)$ & $102(100 \%)$ & $8(100 \%)$ & $6(100 \%)$ & $400(100 \%)$ & \\
\hline
\end{tabular}

The result of Table 2 shows that more males $177(56.0 \%)$ than females $139(44.0 \%)$ had positive attitude towards made in Nigeria goods if the quality and durability are improved upon. Also $36(42.9 \%)$ and $489(57.1 \%)$ for males and females respectively had negative attitude towards made in Nigeria goods even if the quality is improved upon. The chi-square test value shows a very significant relationship between sex and attitude towards made in Nigeria goods if the quality and durability are improved upon.

The result of Table 2 reveals that for those participants who prefer made in Nigeria goods to foreign goods if the quality and durability is improved upon, 308(97.5\%) were Christians, $5(1.6 \%)$ of the participants were Muslims while $3(.9 \%)$ of them were ATR. For the participants who had negative attitude towards made in Nigeria goods even if the quality is improved upon, $81(96.4 \%)$ of them were Christians, 3(3.6) of them were Muslims and none is of ATR. The result shows that more Christians $308(97.5 \%)$ will prefer Nigerian made goods to foreign made if the quality is improved upon. It also shows that residents of the study area, Benin City are predominantly Christians. The chi-square value shows a significant statistical relationship between participants' religion and attitude towards preference of Nigerian made goods if the quality and durability are improved upon.

The result of Table 2 shows that more singles $177(56.0 \%)$ than married $139(44.0 \%)$ of the participants had a positive attitude towards made in Nigeria goods if the quality and durability are improved upon. Also $45(53.6 \%)$ and $39(46.4 \%)$ for single and married respectively had negative attitude towards made in Nigeria goods even if the quality is improved upon. The chi square test value shows no significant relationship between marital status and attitude toward made in Nigeria goods if the quality and durability are improved upon.

From Table 2 above, there were two levels of education- the low and high. Those with primary 
school/secondary school and technical school were the group with low education while those with NCE/OND/HND and B.sc/M.Sc. and above belong to those with high education. The table indicates that for those participants who had positive attitude towards made in Nigeria goods to foreign made goods if the quality and durability are improved upon, 52(16.5\%) were with low education, $264(83.5 \%)$ were those with high education. This group participants who had negative attitude towards made in Nigeria goods said they change their attitude if the quality and durability are improved upon, had low education, $75(89.3 \%)$ had high education. Therefore, the attitude of the participants towards made in Nigeria goods was determined by the level of education. The chi square value shows a significant relationship between education of the participants and the type of attitude towards made in Nigeria goods/foreign goods.

The result from the table indicates that for those participants who prefer to buy Nigerian made goods if opportunity is given, $14(15.7 \%)$ were with low education and $75(84.3 \%)$ were those with high education. For those participants who prefer to buy foreign made good, $38(14.9 \%)$ had low education, $217(85.1 \%)$ had high education and those who had no preference $9(16.1 \%)$ had low education, $47(83.9 \%)$ had high education Therefore, the attitude of the participants towards the preference to buy made in Nigeria goods if opportunity is given is not determined by the level of education. The chi square value shows no significant relationship between education of the participants and degree of attitude to buy made in Nigeria goods or foreign made goods.

The result from the table shows that out of the participants that think Made in Nigeria goods are of poor quality 192(67.6\%) were younger participants while 92(32.4\%) were older participants. Among those participants who think made in Nigeria goods are imitation, $85(83.3 \%)$ were the younger participants and $17(16.7 \%)$ were the older participants while those participants who think made in Nigeria goods are not easily available, $8(100 \%)$ were the younger participants. Lastly, those participants who think made in Nigeria goods are very high in quality, $3(50.0 \%)$ were the younger participants and also $3(50.0 \%)$ were the older participants. The implication is that the positive or negative attitude towards made in Nigeria goods depends on the ages of the participants. The chi-square value shows a significant statistical difference between the ages of the participants and attitude towards made in Nigeria goods. Therefore, we reject the hypothesis which says that there is no significant differences between age of participants and attitude towards made in Nigeria goods.

Hypothesis two states the income differences of participants and their attitude towards made in Nigeria goods. In contingency table 2, the participants' income were divided into two, the low income participants and the high income participants. To get each of the groups, those participants whose income were between N40, 000-N80, 000 belong to the low income participants while those whose income were N81, 000 - 121,000 monthly income and above were those of high income participants.

The result from the table shows that out of the participants that think that made in Nigeria goods are of poor quality $182(64.1 \%)$ were low income earners while $102(35.9 \%)$ were high income earners. Among those participants who think of imitation about made in Nigeria goods, $66(64.7 \%)$ were the low income earners and 36(35.3\%) were the high income earners while those participants who think made in Nigeria goods are not easily available, $7(87.5 \%)$ were the low income earners and $1(12.5 \%)$ was in the high income category. Lastly, those participants who think made in Nigeria goods are very high in quality, 6(100\%) were the low income earners and none was a high income earner. The implication is that the positive or negative attitude towards made in Nigeria goods depends on the income level of the participants. The chi square value shows a significant statistical difference between the income level of the participants and their attitude towards made in Nigeria goods. Therefore, we reject the hypothesis which says that there is no significant difference between income of participants and attitude towards made in Nigeria goods.

Hypothesis three states the differences between occupation level and attitude towards made in Nigeria goods. The result from Table 2 shows that out of the participants that think of poor quality made in Nigeria goods, $189(66.5 \%)$ are employed while $95(33.5 \%)$ are unemployed. Among those participants who think that made in Nigeria goods are imitation, 62(60.8\%) are employed and $40(39.2 \%)$ are unemployed. Of those participants who think made in Nigeria goods are not easily available, $3(62.5 \%)$ are employed and $3(37.5 \%)$ are unemployed. Lastly, those participants who 
think made in Nigeria goods are very high in quality, 5(50.0\%) are employed. The implication is that occupational level of participants influences the attitude towards made in Nigeria goods. The chisquare value shows a significant statistical difference between occupation and attitude towards made in Nigeria goods. Therefore, we reject the hypothesis which says that there is no significant difference between occupation and attitude towards made in Nigeria goods

Hypothesis four states the quality of goods and attitude towards locally made goods. The result from Table 2 shows what the participants think about the poor quality of made in Nigeria goods; $214(75.4 \%)$ said that the quality poor while $70(24.6 \%)$ disagreed. Among those participants who think made in Nigeria goods are imitation, 97(95.1\%) supported the idea of imitation and $6(4.9 \%)$ disagreed. Those participants who think made in Nigeria goods are not easily available, $2(25.0 \%)$ agreed while $6(75.0 \%)$ disagreed. The implication is that the positive or negative attitude towards made in Nigeria goods depends on the quality of goods made in Nigeria. The chi square value shows a significant statistical difference between quality of goods and attitude towards locally made goods. Therefore, we reject the hypothesis which says that there is no significant difference between quality of goods and attitude towards locally made goods.

\section{Summary of Findings}

Findings from the study reveal that majority of the participants from the data obtained were predominantly male participants compared to the female. For example, there were 213 males representing $53.2 \%$ of the total participants against 187 females representing $46.8 \%$. The findings further reveal that the minimum age of the participants was 18 years while the maximum was 50 years. However, the mean age of the participants was 40. It was also revealed that that majority of the participants were single. For example, among the total participants, 222 representing (55.5\%) were single while 168 were married.

The findings also reveal that the participants were predominantly Christians. Majority, 389 $(97.2 \%)$ of the total participants indicated they are Christians. The above finding is a reflection of the peculiarity of the study area, Benin City believed to be the ancestral home of the Benin. In similar vein, the findings also reveal that majority of the participants were of Edo State extraction. This is because the study was done in the Capital City of the State (Edo State). It was also revealed that majority of the participants had higher education with $241(60.2 \%)$ of the total participants are either B.Sc. or M.Sc. holders.

On the monthly income level of participants, the findings reveal majority of the participants representing $171(42.8 \%)$ earned $\mathrm{N} 20,000-\mathrm{N} 40,000$, although the findings also showed that a fraction of the participants earn between N121,000 and above and they represent 53(13.2\%). The findings further reveal that majority of the participants were civil servants and they overwhelmingly said the factor that influences their choice of goods in the market whether foreign or made in Nigeria is the durability of the product. For example, 249 representing $62.2 \%$ of the total participants said they are influenced by the durability of a product. This was far below the percentage for price which people informally held was the reason for the swap in goods.

The findings reveal that majority of the participants prefer foreign goods to Nigerian made goods. These further reinforce the aforementioned factor influencing choice of preference such as the durability of a product. While a fraction of the participants indicated they have no reason to buy made in Nigeria products, no reasons were however indicated. Nevertheless, majority of the participants; $209(52.2 \%)$ said their reason for foreign goods preference is hinged on the quality and durability of such products. That is, goods that last longer is the primary call of consumers and not the cost of a product as it is commonly heard by a select few as the reason for preference. This was in corroboration with the study conducted by Oladele \& Arogundade (2011) on the preference of locally made textile goods among university students which showed that both male and female students admitted they prefer imported goods to locally produced ones.

The findings reveal that the positive or negative attitude towards made in Nigeria goods depends on the quality of goods made in Nigeria. The statistical test shows there is a significant relationship between quality of goods and attitude towards locally made goods. This indicates that the quality of a good is a major factor that influences the preference for the product whether it is 
Nigerian made goods or foreign good. In the in-depth interview, it was revealed that there are some Nigerian made goods such as copper wire; electric cables, for example that are more expensive and also most preferred compared to imported or foreign ones because they are more durable, that is, they last longer than the foreign made ones. The findings also reveal that there is no significant relationship between occupation of participants and their attitude towards made in Nigeria goods. Further hypothesis tested reveals that there is no significant statistical difference between the income level of participants and their attitude towards made in Nigeria goods. This implies that participant incomes have little or no role to play in the choice or preference for a product whether foreign or locally made.

The findings further reveal that there is a significant difference between the ages of the participants and attitude towards made in Nigeria goods. For example, out of the participants that think goods Made in Nigeria are of low quality, $192(67.6 \%)$ were younger participants while 92(32.4\%) were older participants. The participants' belief is a reflection of the perception about made in Nigeria goods as imitation and not original.

\section{Recommendations}

We recommend that manufacturers within the shores of Nigeria should strives to improve on the quality of their products by using high quality raw materials, modern production techniques and technologies so as to meet with the standard of the foreign made goods which have become the major preference for consumers due to the high level of durability of such products.

Quality analysis personnel should be meaningfully engaged. Also quality control agencies such as National Agency for Food and Drug Administration and Control (NAFDAC) and the Standard Organization of Nigeria (SON), should double their efforts at ensuring that goods produced in Nigeria are in conformity with the prescribed and acceptable standards. The regulating agencies should, as a matter of urgency insist on best practice principles and at the same time emphasize zero tolerance for low quality with emphasis on quality and durable products.

It is therefore recommended that government owned and privately owned/ indigenous factories/industries should be supported with the needed finance and advanced technological implements to aid the production of standard goods. Government should as a matter of urgency, give considerable attention to the manufacturing sector to enable it access the required potentials to compete with other industries in foreign countries and their products globally.

\section{Conclusion}

The findings of this study on the attitude of Nigerians towards locally made goods compared to foreign made goods have a lot of implications on the general society and the Nigeria manufacturing sector. It requires government to put necessary machineries in place so as to fulfill the yearnings of consumers in the society.

This study calls for potential areas of future research to further improve the quality of locally manufactured goods in order to be relevant across the globe. The globalization trend as it is also evident in Nigeria, places emphasis on price compared to quality. Durability of a product is a necessary factor considered before a product is procured. There are a few made in Nigeria goods highly consumed or sought after by Nigerians due to their durability. Consumer buying behaviour is very complex, since the purchasing process is conducted in a subjective and personal manner. There are several driving and inhibiting factors which have a dominant influence on buyers' decisions to purchase any good(s) whether imported or locally made. The underlying factor of consumer preference for imported goods or made in Nigeria is trust, i.e. trust for the quality, durability, etc. of the good(s).

\section{References}

Ajzen, I. and Fishbien, M. (1980), The Influence of Attitude on Behaviour Journal of Experimental Psychology 6 466-487 
Althman, I., \&Taylor (1973), Social Penetration: The Development of Interpersonal Relationships. New York: Holt.

Bivens G E (2013) Factors Affecting Consumer Purchase of Goods and Services Available online at www.lib.dr.iastate.edu/cgi/viewcontent.cgi?filename=1\&article=1004\&context. (accessed on 10/01/2018)

Bobby J, Robert C. Burnkrant E (1977) Attribution Theory Approach Journal of Consumer Research, Volume 4, Issue 1, 1 June 1977, Pages 29-38, https://doi.org/10.1086/208676 (accessed on 10/01/18)

Church, A.T. (2006). Implicit theories and self-perceptions of traitedness across cultures Journal of CrossCultural Psychology 37(6) pp 694-716

Fishbien, M.,Ajzen, I., \& McArdle, J. (1980) Changing the behavior of alcoholics: Effects of persuasive communication In I. Ajzen\& M Fishbien [Eds.], Understanding attitudes and predicting social behavior (pp. 217-242). Englewood Cliffs, NJ: Prentice-Hall.

Hofsefede, G. (1994). Management Scientists are Human, Management Science. 40(1): 4-13

Kasl Kollmannova, D (2012) "Fake Products" "Fake Products? Why Fake Products? Why Not? Attitudes toward the Consumption of Counterfeit Goods in CEE as Shown on the example of Slovakia Central European Business Review Research Paper Volume 1, Number 2, October 2012 23-28

Krosnick, J. A. (1988). The role of attitude importance in social evaluation: A study of policy preferences, presidential candidate evaluations, and voting behavior. Journal of Personality and Social Psychology, 55, 196-210.

Lehmann, N. (1979). Trust and Power, Chichester Wiley, UK

Lepper, M.R.; Greene, D., (1984) Undermining Children's Nesbit Intrinsic Interest with Extrinsic Reward: A test of the aver justification hypothesis. Journal of Personality and Social Psychology

Pavlov, P.A. and Chiai, L. (2002) What Drives Electronic-Commerce across Cultures? A Cross-ElectronicCommerce Research

Penz, E.; Schlegemilch, B.B. and Stottinger, B., [2009] Voluntary purchase of counterfeit products: Empirical evidence from four countries Journal of International Consumer Marketing 21(1) 67-84

Petty, R.E. (2003). Persuasion and Attitude Change in T. Mallon \& M.J. Lerner (Eds.) Comprehensive Handbook of Psychology $\left(2^{\text {nd }}\right.$ Ed) New York, John Wiley \& Sons. Available online at www.researchgate.net/22807175_Handbook_of_psychology_second_Edition

Petty, R.E. and Fabrigar, L. (2008), The evolution of theory and research in Social Psychology: From single to multiple effect and process models of persuasion. In C. McCarty \& S.A. Haslam (Eds.) the Message of Social Psychology: Perspectives on Mind in Society. Oxford England Basil Blackwell Ltd

Schwarz, N., \& Boehner, G. (2000). The construction of attitudes In A. Tesser \& N. Schwarz (Eds.), Blackwell handbook of social psychology: Intrapersonal processes. Oxford, UK: Blackwell.

Taylor, S. and Todd, P.A. (1995) Understanding Information Technology Usage: A Test of Competing Models Information Systems Research

Willkie, W.L. (1994) Consumer Behaviour $3^{\text {rd }}$ Edition John Willey \& Sons, Inc. USA. 